Penelitian

\title{
Evaluasi Elektrokardiogram dan Radiografi Paru Domba Diimplan Scaffold Biphasic Calcium Phosphate/Alginate
}

\author{
Electrocardiogram and Pulmonary Radiographic Evaluation on Sheep \\ Implanted with Scaffold Biphasic Calcium Phosphate/Alginate
}

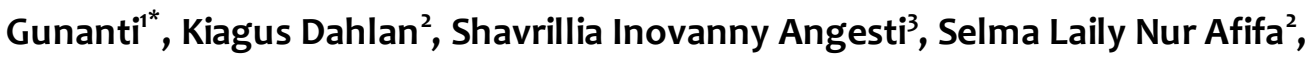 \\ Nuzula Ramadian³, Sugganya A/P Ravi ${ }^{4}$, Soesatyoratih ${ }^{1}$ \\ ${ }^{1}$ Divisi Bedah dan Radiologi, Departemen Klinik, Reproduksi, dan Patologi, \\ Fakultas Kedokteran Hewan, Institut Pertanian Bogor \\ ${ }^{2}$ Departemen Fisika, Fakultas Matematika dan Ilmu Pengetahuan Alam, Institut Pertanian Bogor \\ ${ }^{3}$ Mahasiswa Pendidikan Profesi Dokter Hewan, Fakultas Kedokteran Hewan, Institut Pertanian Bogor \\ ${ }^{4}$ Mahasiswa Program Sarjana. Fakultas Kedokteran Hewan, Institut Pertanian Bogor \\ *Penulis untuk korespondensi: gunanti.soe@gmail.com \\ Diterima: 3 Mei 2020, Disetujui: 24 Juni 2020
}

\begin{abstract}
ABSTRAK
Biomaterial merupakan suatu bahan yang digunakan untuk membantu persembuhan tulang sehingga mempunyai resiko terhadap organ jantung dan paru. Penanaman implan tulang dapat menyebabkan bone cement implantation syndrome yang dapat mempengaruhi aktivitas jantung. Degradasi implan pada tulang dapat menyebabkan efek pada paru. Penelitian ini bertujuan mengevaluasi perubahan pada hasil elektrokardiografi jantungdan radiografi paru domba (Ovis aries) yang diimplan scaffold biphasic calcium phosphate/alginate pada tulang tibia. Penelitian ini menggunakan 3 ekor domba jantan berusia 1.5 tahun dengan berat rata-rata $20 \mathrm{~kg}$. Penanaman implan scaffold BCP/alginate dilakukan secara aseptis pada sepertiga proximal medial tulang tibia. Perekaman EKG pada domba dilakukan dalam keadaan sadar dan posisi berbaring lateral recumbency serta pemeriksaan radiografi dengan standar pandang left lateral recumbency dilakukan pada sebelum dan sesudah operasi, hari ke-7, 30, 60, dan 90 sesudah operasi. Parameter yang dievaluasi berupa amplitudo dan durasi gelombang P, durasi komplek QRS, durasi interval PR, amplitudo R, amplitudo T, durasi interval QT, durasi segmen ST, dan gambaran radiografi toraks. Data elektrokardiogram diolah menggunakan Microsoft Excel 2007 dan IBM Statistical Product and Service Solutions (SPSS). Data variabel dianalisis secara statistik dengan menggunakan metode One Way Analyse of Variant (ANOVA), kemu dian dilanjutkan dengan uji Duncan pada selang kepercayaan 95\%. -Aktivitas elektrokardiografi jantung dan gambaran radiografi paru domba tidak mengalami perubahan setelah memperoleh penanaman implan scaffold BCP/alginate.
\end{abstract}

Kata kunci: implan BCP, elektrokardiografi, radiografi paru, domba

\begin{abstract}
Biomaterial is a material used to help heal bones so that has risks to the heart and lung organs. Implanting bone implants can cause bone cement implantation syndrome which can affect heart activity. Degradation of the implant in the bone can cause effects on the lung. This study aims to evaluate changes incardiac electrocardiographic and radiographic results of sheep (Ovis aries) lung implanted with biphasic calcium phosphate/alginate scaffold in the tibia bone. This study used 1.5 years old rams with average weight of $20 \mathrm{~kg}$. The implantation of $\mathrm{BCP} /$ alginate scaffold implant was performed aseptically on the one third of proximal medial of the tibial bone. ECG recording in sheep is done in a conscious state and lateral recumbency lying position and radiographic examination with left lateral recumbency viewperformed before and after surgery, and on the $7^{\text {th }}, 30^{\text {th }}, 60^{\text {th }}$, and $90^{\text {th }}$ day after surgery. The parameters evaluated are the amplitude and duration of the $P$ wave, the duration of the QRS complex, the duration of the PR interval, the amplitude of $\mathrm{R}$ wave, the amplitude of $\mathrm{T}$ wave, the duration of the QT interval, the duration of the ST segment, and the pulmonary radiographic image. Electrocardiogram datas areprocessed using Microsoft Excel 2007 and IBM Statistical Product and Service Solutions (SPSS). Varable data are analye statistically with one way analyze of variant(ANOVA), then are continued with Duncan test at reliability range $95 \%$. The electrocardiographic activity of the sheep's heart and radiographic images of sheep's lungs did not change after obtaining the implantation of a BCP/alginate scaffold.
\end{abstract}

Keywords: BCP implants, electrocardiography, pulmonary radiographs, sheep 


\section{PENDAHULUAN}

Fraktur merupakan salah satu kasus yang sering terjadi pada hewan. Fraktur pada hewan umumnya disebabkan oleh trauma seperti terbentur benda keras, tertabrak kendaraan dan jatuh dari tempat yang tinggi (Wirata, 2015). Salah satu metode penanganan fraktur adalah reduksi (Smeltzer dan Bare, 2002). Reduksi adalah metode manipulasi tulang untuk mengembalikan kelurusan, posisi, dan panjang dengan mengembalikan fragmen tulang sedekat mungkin (Black dan Hawks, 2014).

Salah satu metode reduksi yang dilakukan untuk mengembalikan fungsi tulang adalah dengan penggunaan bahan biomaterial dan teknikimplantasi untuk menggantikan jaringan tulang yang hilang atau rusak. Aplikasibiomaterial biasanya digunakan untuk menggantikan atau mengembalikanfungsi dari komponen tulang yang mengalami kegagalan atau kerusakan (Ige et al., 2009). Material tersebut diharuskan memiliki beberapa persyaratan, antara lain tidak menimbulkan pengaruh buruk pada tubuh, memiliki ketahanan terhadap korosi, dan memiliki bentukyang kuat (Bombac et al., 2007). Biomaterial implan telah dikembangkan oleh beberapa penelitiyang memiliki semua sifat tersebut adalah biphasic calciumphosphate (BCP), sebab tersusun dari hydroxyapatite dan tricalcium phosphate yang merupakan kandidat scaffold yang memiliki biokompatibilitas baik, biodegradable, dan tidak beracun (Sopyan et al., 2007).

Penggunaan implan tulang memungkinkan adanya pengaruh terhadap kondisi tubuh. Penelitian Donaldson et al.,(2009)menunjukkan bahwa terdapat efek samping pada metode implan tulang berupa bone cement implantation syndrome, yaitu komplikasi yang terjadi pada pasien yang menjalani operasi implan semen tulang.

Penelitian inimenggunakan hewan model berupa domba. Pearce et al. (2007)menyatakan bahwa dalam penelitian ortopedik, salah satu hewan yang dianggap layak untuk percobaan implantasi material sebagai model bagi manusia adalah domba. Penelitian ini bertujuan mengevaluasi perubahan pada hasil elektrokardiografi jantung dan radiografi paru domba (Ovis aries) yang diimplan scaffold biphasic calcium phosphate/alginate pada tulang tibia.

\section{METODE PENELITIAN}

Tempat dan Waktu Penelitian

Penelitian dilakukan mulai bulan Januari hingga April 2017. Operasi penanaman implan tulang, pengambilan data elektrokardiogram, dan pemeriksaan radiografi dilakukan di Laboratorium Divisi Bedah dan Radiologi, Departemen Klinik, Reproduksi dan Patologi, Fakultas Kedokteran Hewan, Institut Pertanian Bogor. Pemeliharaan hewan dilakukan di kandang Unit Pengelolaan Hewan dan Laboratorium (UPHL), Fakultas Kedokteran Hewan, Institut Pertanian Bogor. Seluruh prosedur dalam penelitian ini telah mendapat persetujuan dari Komisi Etik Hewan Fakultas Kedokteran Hewan Institut Pertanian Bogor dengan menerbitkan Sertifikat Persetujuan Etik Hewan nomor 052/KEH/SKE/I/2017.

\section{Alat dan Bahan}

Peralatan yang digunakan pada penelitian ini adalah peralatan bedah minor steril, alat bedah tulang, pisau bedah no. 10 , syringe $1 \mathrm{~mL}, 3 \mathrm{~mL}, 5 \mathrm{~mL}$, dan $10 \mathrm{~mL}$, IV catheter $22 \mathrm{G}$, infus set, oksimeter, mesin elektrokardiografi (EKG), dan kertas rekam EKG, hair dryer, hanger, bak pencuci, mesin x-ray, dan lampu iluminator.

Bahan-bahan yang digunakan pada penelitian ini adalah oxfendazole bolus, oxytetracycline long acting, bahan anestesi (ketamine $\mathrm{HCl} 10 \%$, xylazine $\mathrm{HCl} 10 \%$ ), bahan implan scaffold 3D (dengan poros) $\mathrm{BCP} /$ alginate (diameter $0.8 \mathrm{~cm}$ dan tebal $0.4 \mathrm{~cm}$ ) rasio HA:TCP 70:30, procaine benzyl penicillin (penicillin G) 3.000.000 IU, benang jahit chromic cat gut $3 / 0$, benang jahit silk 2/0, antiseptik (alkohol $70 \%$ ), povidon iodin $3 \%$, salep perubalsem, salep gentamicin, limoxin spray, analgesik (flunixin meglumine), infus $\mathrm{NaCl} 0.9 \% 500 \mathrm{~mL}$, kassa, plester micropore, tampon bedah, gel EKG, larutan developer dan fixer, kertas film ukuran $24 \times 30$, dan pakan hewan. Hewan model yang digunakan pada penelitian ini adalah tiga ekor domba lokal jantan dengan berat badan rata-rata $20 \mathrm{~kg}$ dan berusia 1.5 tahun.

\section{Persiapan Sampel Scaffold BCP/Alginate}

Persiapan bahan implan scaffold $\mathrm{BCP} /$ alginate telah dilakukan di Departemen Fisika, Fakultas Matematika dan Ilmu Pengetahuan Alam, Institut Pertanian Bogor.

\section{Aklimatisasi Hewan Coba}

Tiga ekor diaklimatisasi selama 14 hari. Domba dirawat, diberi pakan dua kali sehari dan minum ad libitum, dan kandang setiap hari dibersihkan selama masa aklimatisasi. Domba 
diberi anthelmintic (oxfendazole) dan antibiotik (oxytetracycline long acting). Pemeriksaan klinis, radiologi, dan pemeriksaan darah dilakukan sebelum hewan dioperasi.

\section{Penanaman Implan Scaffold BCP/Alginate}

Pembiusan dilakukan pada domba dengan pemberian anestesi kombinasi ketamin 10\% dengan dosis $2 \mathrm{mg} / \mathrm{kg}$ BB dan xylazin $10 \%$ dengan dosis $0.1 \mathrm{mg} / \mathrm{kg}$ BB. Kombinasi keduanya diberikan melalui intravena (vena jugularis). Pencukuran bulu dilakukan setelah hewan terbius pada bagian medial tulang tibia kaki kiri dan kaki kanan lalu didesinfeksi dengan alkohol $70 \%$ dan larutan iodin selanjutnya hewan dibawa ke ruangan operasi. Operasi dimulai dengan melakukan sayatan pada kulit. Orientasi sayatan dilakukan di bagian medial persendian lutut, ditarik $5.7 \mathrm{~cm}$ ke arah distal, dan $3.6 \mathrm{~cm}$ dari volar ke dorsal.

Tulang tibia bagian medial dibuat defek dengan cara pengeboran. Kaki kiri sebagai kontrol positif, dibuat defek namun tidak diimplan dengan scaffold BCP/alginate, sedangkan kaki kanan sebagai perlakuan, dibor lalu diimplan dengan scaffold $\mathrm{BCP} /$ alginate. Implan scaffold $\mathrm{BCP} /$ alginate pada tulang tibia dilakukan dengan operasi secara aseptis. Penanaman implan dilakukan pada bagian medial tulang tibia kanan dengan menggunakan bor tulang untuk membuat defek sesuai dengan ukuran implan (diameter $0.8 \mathrm{~mm}$ dan panjang $0.4 \mathrm{~mm}$ ).

Pembuatan defek dibuat melalui sayatan kulit terlebih dahulu. Setelah penanaman implan scaffold $\mathrm{BCP} /$ alginate, tulang kemudian ditutup berturutturut yaitu penjahitan pada lapisan otot dengan benang catgut chromic $3 / 0$, jaringan subkutan dan kulit dengan benang silk 2/0. Setiap lapisan penjahitan diberi antibiotik penicillin $\mathrm{G} 50.000 \mathrm{IU} / \mathrm{ml}$ sebanyak 1 $\mathrm{ml}$ diberikan secara topikal. Metode yang sama juga dilakukan pada tulang tibia kiri. Operasi dilakukan oleh operator yang sama untuk mencegah variasi operasi. Luka akibat operasi kemudian dibersihkan setiap hari dengan povidon iodin 3\% dan diberi salep perubalsem untuk mencegah terjadinya infeksi pascaoperasi selama 7 hari.

\section{Pengambilan Data Elektrokardiogram}

Pengambilan data elektrokardiogram (EKG) pada domba dilakukan dalam keadaan berbaring right lateral, dengan restraint manual dan tanpa menggunakan sedasi. Perekaman EKG dilakukan sebelum dan setelah domba operasi penanaman implan (hari ke-0), hari ke-7,
30, 60, dan 90. Perekaman EKG dilakukan dengan mesin elektrokardiograf yang telah dikalibrasi 1 $\mathrm{mV}=10 \mathrm{~mm}$ dengan kecepatan kertas 25 $\mathrm{mm} /$ detik.

Perekaman EKG menggunakan tiga sandapan bipolar standar (sadapan I, II, III) dan tiga sandapan unipolar (sadapan aVR, aVL, dan aVF) direkam dengan klip EKG sebagai elektroda EKG. Elektroda EKG berjumlah empat buah yang berwarna merah, kuning, hijau, dan hitam. Elektroda EKG ditempatkan pada tubuh domba di bagian ekstremitas. Elektroda EKG warna merah ditempatkan pada kaki depan kanan, kuning pada kaki depan kiri, hijau pada kaki belakang kiri, dan hitam pada kaki belakang kanan domba. Bagian tubuh domba yang akan ditempatkan elektroda dicukur dan diberi gel EKG.

\section{Pemeriksaan Radiografi Toraks}

Ketiga domba yang digunakan dalam penelitian ini dilakukan radiografi toraks pada saat praoperasi, serta pada hari ke-30, hari ke-60, dan hari ke-90 pascaoperasi di ruang radiologi. Hewan dibaringkan dengan standar pandang left lateral recumbency. Hasil radiografi diproses di ruang gelap, dikeringkan dengan hair dryer, dan diinterpretasi dengan bantuan lampu iluminator.

\section{Analisis Data}

Data elektrokardiogram diolah menggunakan Microsoft Excel 2007 dan IBM Statistical Product and Service Solutions (SPSS). Data variabel dianalisis secara statistik dengan menggunakan metode One Way Analyse of Variant (ANOVA), kemudian dilanjutkan dengan uji Duncan pada selang kepercayaan 95\%. Pembahasan hasil analisis data EKG disajikan secara deskriptif. Data radiogram dianalis secara deskriptif yang disajikan dalam tabel dan gambar.

\section{HASIL}

\section{Evaluasi Data Elektrokardiogram}

Hasil penelitian menunjukkan nilai amplitu do dan durasi rata-rata gelombang $\mathrm{P}$ pada hari ke-o (praoperasi dan pascaoperasi), 7, 30, 60, dan 90 tidak terdapat perbedaan nyata ( $P>0.05)$ (Tabel 1). Nilai durasi rata-rata interval kompleks QRS pada hari ke-o (praoperasi dan pascaoperasi), 7, 30, 60, dan 90 tidak terdapat perbedaan nyata $(P>0.05)$ (Tabel1). Nilai amplitudo rata-rata gelombang $R$ 
pada hari ke-o (praoperasi dan pascaoperasi), 7, 30, 60 , dan 90 tidak terdapat perbedaan nyata $(P>0.05)$ (Tabel 1). Nilai durasi rata-rata gelombang PR pada hari ke-o (praoperasi dan pascaoperasi), 7, 30, 60, dan 90 tidak terdapat perbedaan nyata $(P>0.05)$ (Tabel 2). Nilai amplitudo rata-rata gelombang $T$ pada hari ke-o (praoperasi dan pascaoperasi), 7, 30, 60 , dan 90 tidak terdapat perbedaan nyata $(P>0.05)$ (Tabel 2). Nilai durasi rata-rata interval QT pada hari ke-o (praoperasi dan pascaoperasi), 7, 30, 60, dan 90 tidak ditemukan perbedaan nyata $(P>0.05)$ (Tabel 2). Nilai durasi rata-rata segmen ST pada hari ke-o (praoperasi dan pascaoperasi), 7, 30, 60, dan 90 tidak ditemukan perbedaan nyata $(P>0.05)$ (Tabel 2).

\section{Evaluasi Data Radiogram}

Hasil gambaran radiografi dari ketiga domba diambil sebelum melakukan operasi penanaman implam (praoperasi), hari ke-30, hari ke-60, dan hari ke-90 yang diambil pada kVp 66 dan mAs 1,2. Semua hasil tersebut diambil pada posisi left lateral recumbency. Gambaran radiografi paru praoperasi dan pascaoperasi hingga hari ke-9o tidak menunjukkan adanya perubahan terhadap arteri dan vena pulmonalis, peribronchial pattern, cotton like densities, dan lobar sign. Hasil radiografi dapat dilihat pada Gambar 1, Tabel 3, dan Tabel 4.

\section{PEMBAHASAN}

\section{Evaluasi Data Elektrokardiogram}

Evaluasi data elektrokardiogram(EKG) dilakukan pada sadapan II dalam penelitian ini. Pembacaan rekaman EKG dapat dilakukan pada semua sadapan, namun sadapan II paling sering digunakan karena mencatat perbedaan potensial kelistrikan jantung yang paling besar (Karim dan Kabo, 1996). Nilai EKG

Tabel 1 Rata-rata amplitudo gelombang P (mV), durasi gelombang P (detik), durasi kompleks QRS (detik), dan amplitudo gelombang $\mathrm{R}(\mathrm{mV}$ ) berdasarkan waktu pengamatan (hari)

\begin{tabular}{ccccc}
\hline $\begin{array}{c}\text { Waktu } \\
\text { Pengamatan(hari) }\end{array}$ & $\begin{array}{c}\text { Amplitudo gelombang } \\
\mathrm{P}(\mathrm{mV})\end{array}$ & $\begin{array}{c}\text { Durasi gelombang P } \\
(\text { detik) }\end{array}$ & $\begin{array}{c}\text { Durasi kompleks QRS } \\
(\text { detik) }\end{array}$ & $\begin{array}{c}\text { Amplitudo } \\
\text { gelombang R (mV) }\end{array}$ \\
\hline Praoperasi & $0.0600 \pm 0.0529^{\mathrm{a}}$ & $0.0183 \pm 0.0161^{\mathrm{a}}$ & $0.0300 \pm 0.0085^{\mathrm{a}}$ & $0.1367 \pm 0.0723^{\mathrm{a}}$ \\
Pascaoperasi & $0.0400 \pm 0.0346^{\mathrm{a}}$ & $0.0137 \pm 0.0127^{\mathrm{a}}$ & $0.0473 \pm 0.0144^{\mathrm{a}}$ & $0.0733 \pm 0.0666^{\mathrm{a}}$ \\
7 & $0.0833 \pm 0.0115^{\mathrm{a}}$ & $0.0263 \pm 0.0042^{\mathrm{a}}$ & $0.0400 \pm 0.0050^{\mathrm{a}}$ & $0.0500 \pm 0.0436^{\mathrm{a}}$ \\
30 & $0.0800 \pm 0.0462^{\mathrm{a}}$ & $0.0280 \pm 0.0162^{\mathrm{a}}$ & $0.0430 \pm 0.0248^{\mathrm{a}}$ & $0.1100 \pm 0.0635^{\mathrm{a}}$ \\
60 & $0.0900 \pm 0.0520^{\mathrm{a}}$ & $0.0300 \pm 0.0173^{\mathrm{a}}$ & $0.0287 \pm 0.0090^{\mathrm{a}}$ & $0.0000 \pm 0.0000^{\mathrm{a}}$ \\
90 & $0.1050 \pm 0.0710^{\mathrm{a}}$ & $0.0270 \pm 0.0147^{\mathrm{a}}$ & $0.0390 \pm 0.0020^{\mathrm{a}}$ & $0.0900 \pm 0.0636^{\mathrm{a}}$ \\
Nilai normal & $0.13 \pm 0.02$ & $0.040 \pm 0.004$ & $0.0600 \pm 0.010$ & $0.802 \pm 0.438$ \\
\hline Keterangan: huruf superscript yang sama pada baris yang berbeda menyatakan tidak terdapat perbedaan nyata (P>0.05)
\end{tabular}

Tabel 2 Rata-rata durasi gelombang PR(detik), amplitudo gelombang T(mV), durasi interval QT (detik), dan durasi segmen ST (detik) berdasarkan waktu pengamatan (hari)

\begin{tabular}{lcccc}
\hline $\begin{array}{c}\text { Waktu } \\
\begin{array}{c}\text { Pengamatan } \\
\text { (hari) }\end{array}\end{array}$ & Durasi interval PR (detik) & $\begin{array}{c}\text { Amplitudo } \\
\text { gelombang T }(\mathrm{mV})\end{array}$ & $\begin{array}{c}\text { Durasi interval QT } \\
(\text { detik })\end{array}$ & $\begin{array}{c}\text { Durasi segmen ST } \\
(\text { detik) }\end{array}$ \\
\hline Praoperasi & $0.0670 \pm 0.0588^{\mathrm{a}}$ & $0.0700 \pm 0.0141^{\mathrm{a}}$ & $0.3130 \pm 0.1807^{\mathrm{a}}$ & $0.0167 \pm 0.0058^{\mathrm{a}}$ \\
Pascaoperasi & $0.0777 \pm 0.0686^{\mathrm{a}}$ & $0.0200 \pm 0.0116^{\mathrm{a}}$ & $0.0000 \pm 0.0000^{\mathrm{a}}$ & $0.0167 \pm 0.0058^{\mathrm{a}}$ \\
7 & $0.0947 \pm 0.0106^{\mathrm{a}}$ & $0.1367 \pm 0.0666^{\mathrm{a}}$ & $0.1933 \pm 0.1681^{\mathrm{a}}$ & $0.0200 \pm 0.0116^{\mathrm{a}}$ \\
30 & $0.0985 \pm 0.0497^{\mathrm{a}}$ & $0.0800 \pm 0.0116^{\mathrm{a}}$ & $0.2730 \pm 0.1930^{\mathrm{a}}$ & $0.0150 \pm 0.0070^{\mathrm{a}}$ \\
60 & $0.0623 \pm 0.0554^{\mathrm{a}}$ & $0.0767 \pm 0.0282^{\mathrm{a}}$ & $0.2610 \pm 0.1507^{\mathrm{a}}$ & $0.0200 \pm 0.0000^{\mathrm{a}}$ \\
90 & $0.0805 \pm 0.0467^{\mathrm{a}}$ & $0.1450 \pm 0.0131^{\mathrm{a}}$ & $0.2300 \pm 0.1626^{\mathrm{a}}$ & $0.0200 \pm 0.0141^{\mathrm{a}}$ \\
Nilai normal & $0.1400 \pm 0.0120$ & $0.1400 \pm 0.0100$ & $0.26 \pm 0.03$ & $0.1200 \pm 0.010$ \\
\hline Keterangan: huruf superscript yang sama pada baris yang berbeda menyatakan tidak terdapat perbedaan nyata (P>0.05)
\end{tabular}


Tabel 3 Hasil pengamatan ada atau tidak adanya kelainan gambaran radiografi berupa dilatasi vena pulmonalis dan peribronchial pattern

\begin{tabular}{|c|c|c|c|c|c|c|c|c|c|c|c|c|}
\hline \multirow{4}{*}{ Hari ke- } & \multicolumn{12}{|c|}{ Pengamatan } \\
\hline & \multicolumn{6}{|c|}{ Dilatasi vena pulmonalis } & \multicolumn{6}{|c|}{ Peribronchial pattern } \\
\hline & \multicolumn{2}{|c|}{ Domba 1} & \multicolumn{2}{|c|}{ Domba 2} & \multicolumn{2}{|c|}{ Domba 3} & \multicolumn{2}{|c|}{ Domba 1} & \multicolumn{2}{|c|}{ Domba 2} & \multicolumn{2}{|c|}{ Domba 3} \\
\hline & Ada & $\mathrm{TA}$ & Ada & TA & Ada & TA & Ada & TA & Ada & TA & Ada & TA \\
\hline Praoperasi & & $\checkmark$ & & $\checkmark$ & & $\checkmark$ & & $\checkmark$ & & $\checkmark$ & & $\checkmark$ \\
\hline 30 & & $\checkmark$ & & $\checkmark$ & & $\checkmark$ & & $\checkmark$ & & $\checkmark$ & & $\checkmark$ \\
\hline 60 & & $\checkmark$ & & $\checkmark$ & & $\checkmark$ & & $\checkmark$ & & $\checkmark$ & & $\checkmark$ \\
\hline 90 & & $\checkmark$ & & $\checkmark$ & & $\checkmark$ & & $\checkmark$ & & $\checkmark$ & & $\checkmark$ \\
\hline
\end{tabular}

Keterangan: $\mathrm{TA}=$ Tidak ada

Tabel 4 Hasil pengamatan ada atau tidak adanyakelainan gambaran radiografi berupa cotton like density dan lobar sign

\begin{tabular}{|c|c|c|c|c|c|c|c|c|c|c|c|c|}
\hline \multirow{4}{*}{ Hari ke- } & \multicolumn{12}{|c|}{ Pengamatan } \\
\hline & \multicolumn{6}{|c|}{ Cotton like density } & \multicolumn{6}{|c|}{ Lobar sign } \\
\hline & \multicolumn{2}{|c|}{ Domba 1} & \multicolumn{2}{|c|}{ Domba 2} & \multicolumn{2}{|c|}{ Domba 3} & \multicolumn{2}{|c|}{ Domba 1} & \multicolumn{2}{|c|}{ Domba 2} & \multicolumn{2}{|c|}{ Domba 3} \\
\hline & Ada & TA & Ada & TA & Ada & TA & Ada & TA & Ada & TA & Ada & TA \\
\hline Praoperasi & & $\sqrt{ }$ & & $\checkmark$ & & $\checkmark$ & & $\checkmark$ & & $\checkmark$ & & $\checkmark$ \\
\hline 30 & & $\checkmark$ & & $\checkmark$ & & $\checkmark$ & & $\checkmark$ & & $\checkmark$ & & $\checkmark$ \\
\hline 60 & & $\checkmark$ & & $\checkmark$ & & $\checkmark$ & & $\checkmark$ & & $\checkmark$ & & $\checkmark$ \\
\hline 90 & & $\checkmark$ & & $\checkmark$ & & $\checkmark$ & & $\checkmark$ & & $\checkmark$ & & $\checkmark$ \\
\hline
\end{tabular}

Keterangan: TA= Tidak ada

yang dapat dievaluasi untuk menentukan suatu kondisi jantung adalah amplitudo dan durasi gelombang $\mathrm{P}$, durasi komplek QRS, durasi interval $\mathrm{PR}$, amplitudo $\mathrm{R}$, amplitudo $\mathrm{T}$, durasi interval QT, serta durasi segmen ST (Haryosuprobo et al., 2016).

Setengah bagian pertama gelombang $P$ mewakili depolarisasi atrium kanan, setengah bagian yang lain mewakili depolarisasi atrium kiri (Karim dan Kabo, 1996). Hal tersebut menjadikan gelombang $P$ dapat digunakan untuk menilai pembesaran atrium (Thaler, 2013). Kenaikan amplitudo gelombang $P$ menunjukkan pembesaran atrium yang dapat terjadi akibat adanya edema pulmonum yang menyebabkan congestive heart failure. Penurunan amplitudo gelombang $P$ menunjukkan berkurangnya kemampuan depolarisasi atrium (Thaler, 2013). Nilai normal amplitudo gelombang $P$ pada domba adalah $0.13 \pm$ $0.02 \mathrm{mV}$ (Ahmed dan Sanyal, 2008). Nilai amplitudo rata-rata gelombang $\mathrm{P}$ pada penelitian ini berada pada kisaran normal tersebut, menandakan tidak terdapat gangguan pada depolarisasi atrium dan tidak terjadi pembesaran atrium dengan adanya penanaman implan tulang $\mathrm{BCP} /$ alginate.

Pengukuran durasi gelombang $P$ dilakukan untuk mengetahui waktu depolarisasi atrium. Durasi gelombang P yang meningkat menjadi indikasi terja- dinya pembesaran atrium kiri. Nilai normal durasi gelombang $P$ pada domba adalah $0.040 \pm 0.004$ detik (Ahmed dan Sanyal, 2008). Nilai durasi ratarata gelombang $P$ pada penelitian ini berada pada kisaran normal tersebut, menunjukkan tidak adanya gangguan pada aktivitas atrium dengan adanya penanaman implan tulang $\mathrm{BCP} /$ alginate.

Interval kompleks QRS merupakan gambaran lamanya aktivitas depolarisasi ventrikel melalui berkas His dan serabut Purkinje (Karim dan Kabo, 1996). Pengukuran interval kompleks QRS mampu menunjukkan adanya hipertrofi ventrikel jantung. Hipertrofi ventrikel akan meningkatkan durasi interval kompleks QRS karena penambahan massa otot jantung (Sari, 2005). Penggunaan semen tulang dapat menyebabkan beban emboli yang dapat meningkatkan tekanan arteri pulmonal dan resistensi pembuluh darah pulmonal. Kedua hal tersebut menyebabkan dinding ventrikel kanan membesar (PAPSRS, 2006). Nilai normal durasi interval kompleks QRS pada domba yaitu $0.0600 \pm$ 0.010 detik (Ahmed dan Sanyal, 2008). Nilai durasi rata-rata interval kompleks QRS pada penelitian ini berada pada kisaran normal tersebut, menandakan tidak adanya kelainan pada konduksi ventrikel setelah penanaman implan tulang $\mathrm{BCP} /$ alginate. 


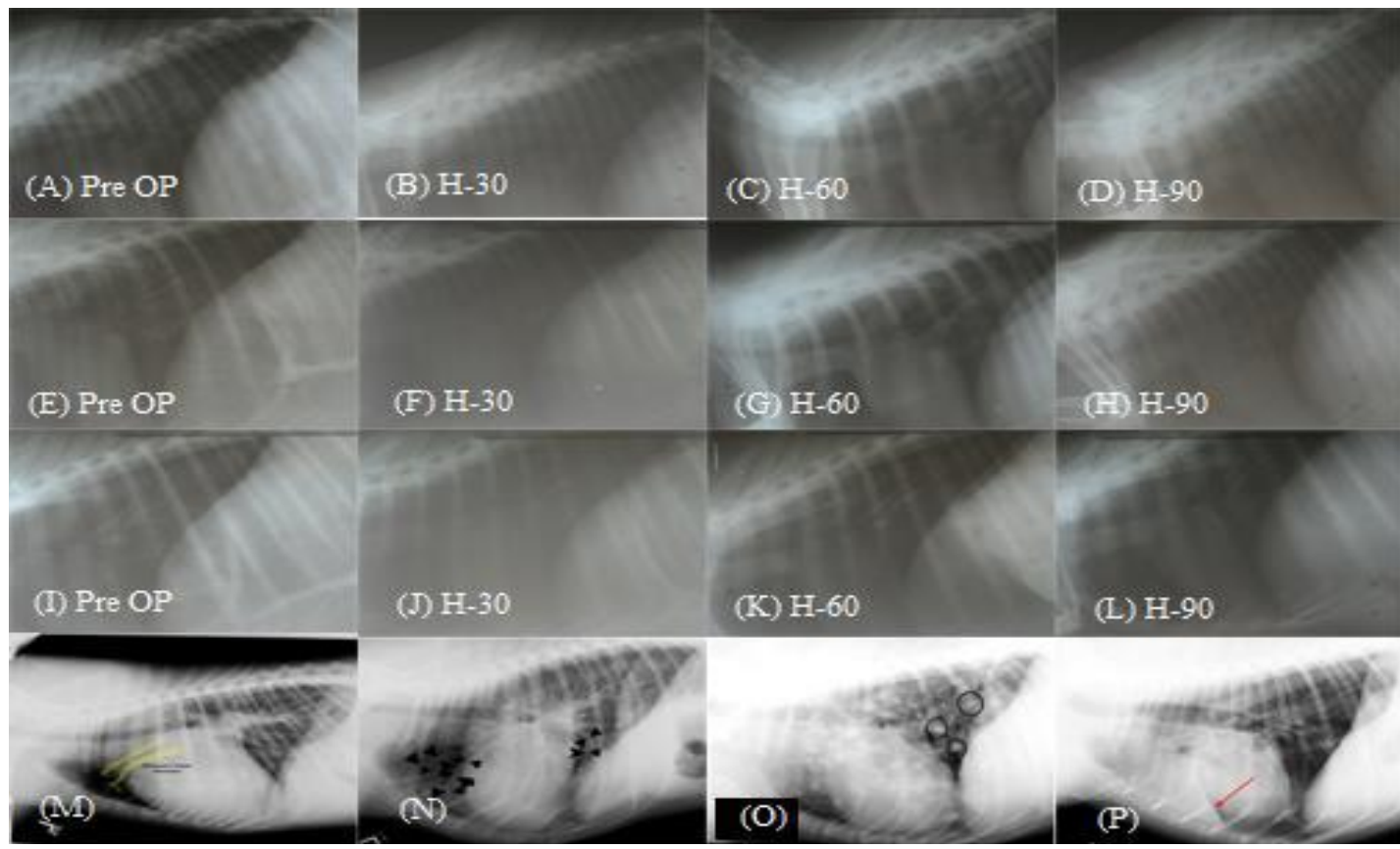

Gambar 1 Radiografi paru pada praoperasi, 30 hari, 60 hari dan 90 hari pascaoperasi domba 1 (A-D), domba 2 (E-H), domba 3(I-L), dan contoh kelainan pada paru (dilatasi vena pulmonalis $(M)$, peribronchial pattern $(\mathrm{N})$, cotton like density $(\mathrm{O})$, lobar sign $(\mathrm{P})$

Pengukuran amplitudo gelombang R dilakukan untuk menggambarkan fase depolarisasi ventrikel. Perubahan pada gelombang $\mathrm{R}$ dapat menggambarkan kondisi hipertrofi dan dilatasi ventrikel. Dilatasi ruang yang terjadi lebih sering pada salah satu ventrikel saja, diikuti penebalan dinding ventrikel tetapi penebalan dinding yang terjadi masih lebih kecil dibandingkan dengan dilatasi ruang ventrikel (Abraham et al., 2012). Nilai normal amplitudo gelombang $\mathrm{R}$ pada domba yaitu $0.802 \pm 0.438 \mathrm{mV}$ (Haryati, 2010). Nilai amplitudo rata-rata gelombang $R$ pada penelitian ini berada pada kisaran normal tersebut. Nilai o pada hari ke60 menunjukkan variasi gelombang QRS berupa gelombang QS pada rekaman EKG. Secara keseluruhan rekaman amplitudo $\mathrm{R}$ menunjukkan tidak ada gangguan pada konduksi ventrikel akibat penanaman implan tulang $\mathrm{BCP} /$ alginate.

Interval PR menggambarkan waktu mulai dari awal depolarisasi atrium sampai awal depolarisasi ventrikel, interval ini mewakili waktu yang dibutuhkan oleh impuls dari nodus SA berjalan melewati nodus AV sampai ke berkas His. Perubahan interval PR menunjukkan gangguan konduksi jalur impuls dari nodus SA hingga melewati nodus AV sampai ke berkas His. Interval PR dapat mengalami percepatan yang terjadi karena adanya aritmia yang berhubungan dengan gangguan impuls jantung (Karim dan Kabo, 1996). Perlambatan interval PR terjadi pada penderita Lown-GanongLevine syndrome yang menampilkan interval $P R$ pendek namun kompleks QRS normal pada EKG (Soos dan McComb, 2019). Nilai normal durasi interval PR pada domba adalah $0.1400 \pm 0.0120$ (Ahmed dan Sanyal, 2008). Nilai durasi rata-rata gelombang PR pada penelitian ini berada pada kisaran normal tersebut, menandakan waktu dari awal depolarisasi atrium sampai awal depolarisasi ventrikel tidak mengalami percepatan atau perlambatan akibat penanaman implan tulang $\mathrm{BCP} /$ alginate.

Gelombang $T$ merupakan gambaran fase repolarisasi ventrikel (Karim dan Kabo, 1996). Gelombang $T$ dapat dipengaruhi oleh keadaan fisiologis maupun keadaan patologis. Keadaan fisiologis dapat berupa olahraga, tidur, atau perut yang penuh setelah makan. Sementara keadaan patologis berupa penyakit jantung, toksemia, penggunaan obat-obatan seperti digitalis (Karim dan Kabo, 1996), hiperkalemia (Guyton dan Hall, 2016), dan iskemia miokardium (Thaler, 2013). Nilai normal amplitudo gelombang $T$ pada domba adalah $0.1400 \pm 0.0100 \mathrm{mV}$ (Ahmed dan Sanyal, 2008). Nilai amplitudo rata-rata gelombang $T$ pada penelitian ini 
berada pada kisaran normal tersebut, menandakan tidak ada kelainan selama repolarisasi ventrikel setelah menerima implan tulang BCP/alginate.

Interval QT merupakan aktivitas total ventrikel (mulai dari depolarisasi hingga repolarisasi ventrikel)(Dharma, 2012). Pemanjangan interval QT disebabkan oleh pemanjangan repolarisasi ventrikel, dapat dipengaruhi oleh obat-obatan seperti antiaritmia, gangguan keseimbangan elektrolit, serta penyakit gagal jantung kongestif (Thaler, 2013). Interval QT yang memanjang mengindikasikan adaya repolarisasi jantung yang ireguler, aritmia ventrikel, dan terjadi peningkatan kematian mendadak (Ganong, 2008). Pemendekan interval QT ditemukan pada pemakaian digitalis, intoksikasi potasium, hiperkalsemia, dan hipertrofi ventrikel kiri (Ganong, 2008). Pemakaian digitalis berlebih menyebabkan durasi depolarisasi pada satu bagian ventrikel dapat meningkat jauh dibanding bagian lainnya (Guyton dan Hall, 2016). Nilai normal durasi interval QT pada domba adalah $0.213 \pm 0.012$ detik (Tajik et al., 2016). Nilai durasi rata-rata interval QT pada penelitian ini berada pada kisaran normal tersebut. Pemendekan dan pemanjangan daerah interval QT juga tidak ditemukan. Pada rekaman pascaoperasi durasi interval QT bernilai o karena rekaman menunjukkan frekuensi jantung yang sangat cepat. Secara keseluruhan berdasarkan rekaman durasi interval QT menunjukkan tidak terdapat gangguan pada aktivitas total ventrikel akibat penanaman implan tulang $\mathrm{BCP} /$ alginate.

Segmen ST merupakan gambaran waktu mulai dari akhir depolarisasi ventrikel sampai awal repolarisasi ventrikel. Perubahan nilai durasi segmen ST dapat menunjukkan kondsi kelainan jantung berupa infark miokard atau iskemia miokard yang ditunjukkan dengan elevasi atau depresi segmen ST (Karim dan Kabo 1996). Nilai normal durasi segmen ST pada domba adalah $0.1200 \pm 0.010$ detik (Ahmed dan Sanyal, 2008). Nilai durasi rata-rata segmen ST pada penelitian ini berada pada kisaran normal tersebut dan tidak terdapat elevasi atau depresi segmen ST, hal tersebut menandakan tidak terjadi iskemia maupun infark miokardium akibat penanaman implan tulang $\mathrm{BCP} /$ alginate.

\section{Evaluasi Data Elektrokardiogram}

Implan pada tulang dapat menyebabkan efek pada paru dengan cara degradasi implan tersebut menjadi molekul calcium dan phosphate, yang dapat merembes ke dalam sel-sel darah di dalam sumsum tulang yang dapat memasuki sistem sirkulasi. Hal ini dapat menyebabkan abnormalitas paru. Kelainan yang dapat dilihat pada paru yang terjadi akibat implan antara lain dilatasi vena pulmonalis, peribronchial pattern, cotton like density, dan juga lobar sign. Bone cement implantation syndrome merupakan salah satu bentuk reaksi penolakan tubuh yang menimbulkan kelainan-kelainan tersebut (Fharantyka, 2014). Bone cement implantation syndrome biasanya ditandai dengan keadaan hipoksia, hipoksemia, peningkatan tekanan pada arteri pulmonari, cardiac arrhytmia, dan cardiac arrest (Razuin et al., 2013). Reaksi penolakan terhadap bahan implan terjadi akibat dari salah satu komponen implan tersebut yaitu methyl methacrylate (MMA) yang merupakan bahan dasar dari implan tersebut. MMA merupakan penyebab utama ketidakstabilan hemodinamik pada saat operasi arthroplasty karena bersifat toksik (Govil et al., 2009).

Biphasic calcium phosphate (BCP) adalah kandidat scaffold yang memiliki biokompatibilitas baik, biodegredable, dan tidak beracun (Sopyan et al., 2007). Hal tersebut menjelaskan bahwa implan scaffold BCP yang digunakan pada penelitian ini bersifat tidak toksik terhadap tubuh sehingga tidak ada efek terhadap paru yang jelas dilihat pada keadaan radiografi paru yang menunjukkan tidak ada kelainan.

Dilatasi vena pulmonalis dapat terlihat jelas pada gambaran radiografi jika vena pulmonalis berukuran lebih besar dari arteri pulmonalis (Gambar $1 \mathrm{M}$ ). Vena pulmonalis dan arteri pulmonalis memiliki ukuran yang sama pada kondisi normal (O'Grady dan O'Sullivan 2004). Dilatasi vena pulmonalis dapat disebabkan oleh kegagalan jantung kiri dan mengakibatkan jantung kehilangan kemampuan untuk memompa cukup darah ke seluruh tubuh yang secara langsung menyebabkan peningkatan tekanan pada ventrikel kiri, atrium kiri, dan vena pulmonalis. Peningkatan tekanan ini mengakibatkan terjadinya pembesaran/dilatasi vena pulmonalis (O'Grady dan O'Sullivan, 2004). Penyempitan katup mitral juga dapat menyebabkan dilatasi vena pulmonalis (Baumgartner et al. 2009). Hasil radiografi menunjukkan bahwa tidak ada perubahan dalam ukuran vena pulmonalis pascaoperasi penanaman implan dilakukan hingga hari ke-90.

Peribronchial pattern adalah kejadian yaitu gambaran radiografi bronchiolus yang kelihatan lebih radioopak akibat dari penebalan dinding bronchiolus (O'Sullivan dan O' Grady, 2004) (Gambar $2 \mathrm{~N}$ ). Cotton like density merupakan suatu kelainan 
pada paru yang terlihat lebih radioopak dan berbentuk seperti kapas secara radiografi (Gambar 9 O). Cotton like density dapat terjadi akibat adanya edema paru interstitialis, hemoragi, pneumonia interstitialis, fibrosis pulmonalis, neoplasia, artefak, obesitas, penyebaran radiasi yang menyebabkan keabu-abuan film, fibrosis geriatric akibat penuaan, neoplasia paru, dan hematoma (Larsen, 2008). Cotton like density tidak ditemukan pada gambaran radiografi paru praoperasi hingga hari ke-9o. Gambaran lobar sign secara radiografi terlihat lebih radioopak pada lobus paru yang mengalami edema (Gambar 9 P). Lobar sign tidak ditemukan pada gambaran radiografi paru penelitian ini.

Nilai amplitudo dan durasi gelombang $P$, durasi kompleks QRS, durasi interval PR, amplitude gelombang $\mathrm{R}$, amplitude gelombang $\mathrm{T}$, durasi interval QT, serta durasi segmen ST pada hasil rekaman EKG domba masih berada pada kisaran normal serta tidak terdapat perbedaan yang nyata. Gambaran radiografi paru menunjukkan hasil yang normal, baik pada praoperasi maupun pascaoperasi hingga hari ke-90. Implan scaffold biphasic calcium phosphate/alginate tidak memberikan efek perubahan terhadap aktivitas jantung dan paru.

"Penulis menyatakan tidak ada konflik kepentingan dengan pihak-pihak yang terkait dalam penelitian ini".

\section{DAFTAR PUSTAKA}

[PAPSRS] Pennsylvania Patient Safety Reporting System. 2006. Bone cement implantation syndrome. Patient Safety Advisory. 3 (4).

Abraham WT, Acker MA, Ackerman MJ, Ades PA, Antman EM, Anversa P. 2012. Braunwald Heart Disease: A Textbook of Vascular Medicine. Philadelphia (US): Elsevier.

Ahmed JA, Sanyal S. 2008. Electrocardiographic studies in garol sheep and black bengal goats. Research Journal of Cardiology. 1(1):1-8.

Baumgartner $\mathrm{H}$, Hung J, Bermejo J, Chambers JB, Evangelista A, Griffin BP, Lung B, Otto CM, Pellikka PA, Quinones M. 2009. Echocardiographic assessment of valve stenosis: EAE/ASE recommendations for clinical practice. European Journal of Echocardiography. 10:1-25.

Black JM, Hawks JH. 2014. Medical Surgical Nursing. Jakarta (ID): Salemba Medika.
Bombac D, Miha B, Fajfar P, Kosel F, Turk R. 2007. Review of materials in medical applications. $R M Z$ Materials and Geoenvironment. 54:471-499.

Donaldson AJ, Thomson HE, Harper NJ, Kenny NW. 2009. Bone cement implantation syndrome. British Journal of Anaesthesia. 102(1):12-22.

Dharma S. 2012. Sistematika Interpretasi EKG Pedoman Praktis. Jakarta (ID): EGC.

Fharantyka I. 2014. Kajian klinis persembuhan kerusakan segmental tulang domba dengan implan biphasic calcium phospate [skripsi]. Bogor (ID): Institut Pertanian Bogor.

Ganong WF. 2008. Fisiologi Kedokteran. Jakarta(ID): EGC.

Guyton AC, Hall JE. 2016. Buku Ajar Fisiologi Kedokteran. Jakarta (ID): EGC.

Govil P, Kakar PN, Arora D, Das S, Gupta N, Govil D, Gupta S, Malohtra A. 2009. Bone cement implantation syndrome: a report of four cases. Indian Journal of Anaesthesia. 53(2):214-218.

Haryati RAD. 2010. Profil elektrokardiogram pada domba lokal (Ovis Aries) setelah penanaman implan semen tulang hidroksiapatit-kitosan dan hidroksiapatit-trikalsium fosfat pada tulang tibia [skripsi]. Bogor (ID): Institut Pertanian Bogor

Haryosuprobo IR, Sugiarto Y, Suryadi FX. 2016. Ekstraksi ciri sinyal EKG aritmia menggunakan gelombang singkat diskrit. Techné Jurnal Ilmiah Elektroteknika. 15(2):149-164.

Ige OO, Umoru LE, Adeoye MO, Adetunji AR, Olorunniwo OE, Akomolafe Il. 2009. Monitoring, control, and prevention practises of biomaterials corrosion-an overview. Trends Biomaterials Artificial Organs. 23:93-104.

Karim S, Kabo P. 1996. EKG dan Penanggulangan Beberapa Penyakit Jantung untuk Dokter Umum. Jakarta (ID): Fakultas Kedokteran Universitas Indonesia.

Larsen MM. 2008. Radiographic evaluation of pulmonary patterns and disease. DVM 360 [Internet]. [diunduh 2017 Agu 5]. Tersedia pada: http://veterinarycalendar.dvm360.com/radiograp hic-evaluation-pulmonary-patterns-and-diseaseproceedings id $=\& s k=\&$ date $=\&$ page $I D=3$

O'Grady MR, O'Sulivan ML. 2004. Clinical radiology concepts. Veterinary Medical Education [Internet]. [diunduh 2017 Mar 07]. Tersedia pada: http://www.vetgo.com

Pearce AI, Pearce SG, Richards RG, Milz S, Schneider E. 2007. Animal models for implant biomaterial research in bone: a review. European Cells and Materials. 13:1-10. 
Razuin R, Effat O, Shahidan MN, Shama DV, Miswan MFM. 2013. Bone cement implantation syndrome. Malaysian Journal of Pathology. 35(1): 87-90.

Sari SI. 2005. Nilai diagnostik beberapa kriteria hipertrofi ventrikel kiri secara elektrokardiografik pada penderita hipertensi dibanding dengan ekokardiografi [tesis]. Semarang (ID): Universitas Diponegoro.

Smeltzer CS, Bare. 2002. Buku Ajar Keperawatan Medikal Bedah. Jakarta (ID): EGC.

Soos MP, McComb D. 2019. Lown Ganong Levine syndrome. Stat Pearls [Internet]. [diakses pada 2020 Jun 17]. Tersedia pada: https://www.ncbi. nlm.nih.gov/books/NBK546711/\#article-24446.s1
Sopyan I, Mel M, Ramesh S, Khalid KA. 2007. Porous hydroxyapatite for artificial bone applications. Science and Technology of Advanced Material. 8:116-123.

Tajik J, Samimi AS, Shojaeepour S, Jarakani S. 2016. Analysis of base-apex lead electrocardiogram in clinically healthy Kermani sheep. Journal of the Faculty of Veterinary Medicine Istanbul University. 42(1):74-79.

Thaler MS. 2013. Satu-satunya Buku EKG yang Anda Perlukan. Jakarta (ID): EGC.

Wirata IW. 2015. Efektivitas Penggunaan demineralized porcine cortical bone xenograft (DPCBX) sebagai bahan cangkok alternatif untuk penanganan fraktur femur pada anjing [tesis]. Yogyakarta (ID): Universitas Gadjah Mada. 